\title{
ASTN2 Gene
}

National Cancer Institute

\section{Source}

National Cancer Institute. ASTN2 Gene. NCI Thesaurus. Code C82894.

This gene may play a role in neural development. 